\title{
Effect of the Ensiled Taro with Rice Wine by Product or Fish Meal Fed Basal Diet of Rice Bran on Digestibility and Nitrogen Retention of Growing Pigs
}

\author{
Chiv Phiny ", Kong Saroeun, Ros Vanchey \\ Faculty of Agriculture, Svay Rieng University, Svay Rieng Province, Cambodia \\ Email address: \\ chiv.phiny@sru.edu.kh (C. Phiny),kong.saroeun@sru.edu.kh (K. Saroeun), rvanchey@sru.edu.kh (R. Vanchey) \\ ${ }^{*}$ Corresponding author
}

To cite this article:

Chiv Phiny, Kong Saroeun, Ros Vanchey. Effect of the Ensiled Taro with Rice Wine by Product or Fish Meal Fed Basal Diet of Rice Bran on Digestibility and Nitrogen Retention of Growing Pigs. Animal and Veterinary Sciences. Vol. 9, No. 1, 2021, pp. $24-31$.

doi: $10.11648 /$ j.avs.20210901.14

Received: March 3, 2021; Accepted: March 16, 2021; Published: March 26, 2021

\begin{abstract}
Eight castrated male crossbred pigs (Large White x Local breed) of average live weight $25 \mathrm{~kg}$ were given four diets in a double $4 * 4$ Latin square arrangement. The experiment included 4 periods, each of 12 days, 7 days for adaptation and 5 days for collection of feces and urine. The pigs were vaccinated against salmonellosis, pasteurellosis and hog cholera. The experiment was carried out from 08th September 2020 to 20th November 2020, at the research station of Svay Rieng University (SRU), located in Svay Rieng Province, Cambodia. The total intakes of DM, CP and OM were higher in the treatments that contained rice wine by product (RW20) and rice wine by product plus fish meal (RW20FM10). As the percentages of CF, NDF and ADF were lower intakes of these fractions in the treatment without used the rice wine by product (RW0) or used rice by product plus fish meal (FM10). There were no consistent differences in apparent digestibility of DM, OM, CP and ADF, except CF and NDF among the diets. The values were relatively high for all the treatments contained rice wine by product while the basal diet of rice brain was mixed but except the values of CF and NDF. The apparent digestibility of DM, OM and CP increased when the diets were mixed with rice wine by product. The values for $\mathrm{N}$ retention, expressed as $\mathrm{g} /$ day or as a percentage of $\mathrm{N}$ intake or $\mathrm{N}$ digested, were highest for the diet with mixed rice wine by product with a tendency for the diet without mixed rice wine by product (FM10) to be also better than the diets without rice wine by product or fish meal (RW0). When the data for $\mathrm{N}$ retention were corrected for differences in $\mathrm{N}$ intake therefore the differences in $\mathrm{N}$ retention were more pronounced in favor of the diets containing rice wine by product (RW20 and RW20FM10) or without rice wine by product (FM10). The conclusion was the supplement of a mixture of the ensiled taro with rice wine by product in the diets contained RW20 and RW20FM10, were higher apparent digestibility of $\mathrm{DM}, \mathrm{CP}, \mathrm{OM}$ and $\mathrm{CF}$, and higher N retention, than when supplement was only ensiled taro without rice wine by product (RW0) or fish meal (FM10), mixed with a basal diet of rice brain.
\end{abstract}

Keywords: Ensiled Taro Foliage, Rice Wine by Product, Fish Meal, Digestibility and N Retention

\section{Introduction}

In Cambodia, the leaves from shrubs such as cassava and mulberry, and from vegetables such as sweet potato, Taro and water spinach, can all be used successfully in diets for pigs to replace part or all of the protein usually supplied as soybean and/or fish meal. On the basis of research so far, it appears that the foliage of taro (Colocasia esculenta), also known as "Old Cocoyam", offers the most potential as a protein supplement to replace fish meal and soybean meal as the digestibility of the protein and its biological value are high. The foliage is relatively low in fiber which is reported to be of higher digestibility than the fiber in other protein-rich forages such as mulberry [3].

Taro plant (Colocacia esculenta) is from the same family of areas. It grows widely in Cambodia, in ponds and waste land. There are two forms of oxalate in taro, one soluble and the other insoluble. The oxalate content was higher in young 
leaves $(589 \pm 36 \mathrm{mg} / 100 \mathrm{~g}$ fresh basis) than in older leaves $(433 \pm 15 \mathrm{mg} / 100$ fresh basis) and that soluble oxalate was $74 \%$ of the total oxalate in the leaves $[2,13]$. In a survey in Cambodia [2] it was found that farmers traditionally "boiled" the leaves before feeding them to pigs as in the fresh state the leaves were not readily consumed. Recently, ensiling of the Taro foliage has been developed [19] and has proved to be effective in reducing the oxalate content [8]. Farmers in Cambodia have experience in using the leaves and stems of this plant usually by cooking them in order to avoid the irritation to the skin when the leaves and stems are fed fresh [2]. This irritation is known to be caused by oxalate salts in both the leaves and stems [9]. Furthermore, ensiled taro leaves have successfully used by mixing with water spinach to replace $100 \%$ of soybean meal in pregnancy and lactation diets for Mong Cai gilts without affecting sow reproduction [4]. Recent research has shown that ensiling the leaves and stems is the most effective way to reduce the concentration of oxalates and that this process is readily accepted by farmers in Vietnam [7]. Rodríguez L and Preston T R (2009) reported the Taro stems are rich in soluble sugars thus when they are incorporated in the silage there is no need for conventional silage additives such as molasses. In addition, the finding that the stem contained a high level of sugars led to the idea of ensiling the leaves and stem together, obviating the need for additional sources of sugars [19].

Rice distillers' by-product or rice wine by product is the residue when rice is fermented and the products of fermentation are then distilled to produce alcohol in an artisan production system. Rice is cooked and yeast is added to the cooked rice for fermentation. The alcohol is distilled from the fermentation liquor, after which the residue is used as a wet feed for pigs. Rice distillers' by-product is produced in large amounts in households in the Mekong delta [10]. Rice distillers' by-product or rice wine by product (known as Bay Srar) is another potential source of high-quality protein in rural areas of Lao PDR. Bay Srar is the residue after distilling the alcohol derived by yeast fermentation of rice [16]. The farmers traditionally use it as a mixture with other feeds such as rice bran and broken rice in diets for fattening pigs [14]. The farmers in Vietnam also use rice distillers' by-product or rice wine by product (Bay Srar) as a traditional feed for pigs [18]. The protein content of "Bay Srar" ranged from 17 to $33 \%$ (mean of $23 \%$ ) in dry matter with a well-balanced array of amino acids [17]. These authors reported that this product could replace completely the fish meal in growing and fattening pig diets with no loss of performance. The rice distillers' by-product has a fairly high protein content $(>20 \%$ crude protein in dry matter) of good quality with respect to the balance of amino acids [10].

The ensiled taro was used successfully by mixing with some protein sources and shown that DM intake and growth rate were increased when a mixture of rice bran and ensiled taro foliage was supplemented with protein-enriched rice or by fish meal. Live weight gain was increased by $36.7 \%$ with supplementation of protein-enriched rice compared with $16.5 \%$ improvement for supplementation with fish meal [5].

The aim of this study therefore was to determine the effects of inclusion of the ensiled taro foliage into the diets containing with or without of rice wine by product fed a basal diet of rice bran on digestibility and nitrogen retention of growing pigs.

\section{Materials and Methods}

\subsection{Location and Climate}

The experiment was carried out from $08^{\text {th }}$ September 2020 to $20^{\text {th }}$ November 2020, at the research station of Svay Rieng University (SRU), located in NR 1, Sangkat Chek, Svay Rieng City, Svay Rieng Province, Cambodia. The ambient temperature was about $37^{\circ} \mathrm{C}$ in the middle of the day.

\subsection{Experimental Design and Treatments}

Eight castrated male crossbred pigs (Large White x Local breed) of average live weight $25 \mathrm{~kg}$ were given four diets in a double $4 * 4$ Latin square arrangement. The experiment included 4 periods, each of 12 days, 7 days for adaptation and 5 days for collection of feces and urine. The pigs were vaccinated against salmonellosis, pasteurellosis and hog cholera. The diets consisted in the addition of the ensiled taro mixed with rice wine by product or fish meal to the basal diet of rice bran:

RW0: Ensiled taro (52\%) and rice bran (48\%)

RW20: RW (20\%) with ensiled taro (50\%) and rice bran $(30 \%)$

FM10: FM (10\%) with ensiled taro (18\%) and rice bran $(72 \%)$

RW20FM10: RW (20\%) with FM (10\%) with ensiled taro $(16 \%)$ and rice bran $(54 \%)$

Table 1. Layout of the experiment.

\begin{tabular}{lllllllll}
\hline Pig & 1 & $\mathbf{2}$ & $\mathbf{3}$ & $\mathbf{4}$ & $\mathbf{5}$ & $\mathbf{6}$ & $\mathbf{7}$ & $\mathbf{8}$ \\
\hline Period & Square 1 & & & & Square 2 & & & \\
\hline I & RW0 & RW20FM10 & FM10 & RW20 & RW20FM10 & RW0 & RW20 & FM10 \\
II & RW20 & RW0 & RW20FM10 & FM10 & RW0 & RW20 & FM10 & RW20FM10 \\
III & FM10 & RW20 & RW0 & RW20FM10 & RW20 & FM10 & RW20FM10 & RW0 \\
IV & RW20FM10 & FM10 & RW20 & RW0 & FM10 & RW20FM10 & RW0 & RW20 \\
\hline
\end{tabular}

The ingredients and chemical composition of the diets are shown in Table 2. 
Table 2. Composition (planned) and chemical composition (calculated by analytical data) of the diets.

\begin{tabular}{llccc}
\hline & RW0 & RW20 & FM10 & RW20FM10 \\
\hline Ingredients & & & & \\
Ensiled Taro (ET) & 52.0 & 50.0 & 18.0 & 16.0 \\
Rice wine by product (RWB) & - & 20.0 & - & 20.0 \\
Fish meal (FM) & - & - & 10.0 & 10.0 \\
Rice bran (RB) & 47.5 & 29.5 & 71.5 & 53.5 \\
Premix plus salt (PS) & 0.50 & 0.50 & 0.50 & 0.50 \\
Chemical composition & & & 67.0 \\
Dry Matter (DM) & 46.7 & 40.1 & 73.6 & 16.2 \\
Crude Protein (CP) & 16.2 & 16.1 & 8.14 \\
Organic Matter (OM) & 78.9 & 83.3 & 76.0 & \\
Crude Fiber (CF) & 18.5 & 17.3 & 9.30 & \\
Neutral Detergent Fiber (NDF) & 36.1 & 32.1 & 30.1 & 26.0 \\
Acid Detergent Fiber (ADF) & 32.7 & 28.5 & 24.8 & \\
\hline
\end{tabular}

\subsection{Experimental Feeds and Feeding}

Rice bran and fish meal were purchased only one time at the beginning of the experiment in the local market. Fresh taro plant was collected from ponds or cannels and produced as taro silage at in the station of Svay Rieng University. In addition, rice wine by product was bought from villagers who make the rice wine as small-scale production.

\subsection{Ensiling the Taro Plant}

Taro leaves and stems were chopped into $2-3 \mathrm{~cm}$ pieces, dried under the sun for 2 hours to reduce moisture content then put into plastic bags with pressing of the material to remove the air inside. Finally, the bags were well tied and stored in the plastic container. The ensiled taro was opened and used to feed the pigs after 20 days.

\subsection{Animals and Housing}

The pigs were housed in metabolism cages made from bamboo and wood fixed to a wooden frame in a composite unit (1.6 m length and $1 \mathrm{~m}$ wide) for 2 pigs per unit that allowed the pigs to move freely. The cages were fitted with automatic water drinkers. The floor area of each metabolism cage was $80 \times 100 \mathrm{~cm}$ and designed to make it possible to collect the feces and urine separately. Plastic netting was suspended below the floor to collect the feces. The urine passed through the plastic net and was collected over a sheet of polyethylene leading to a filter placed in a funnel suspended over a plastic bucket.

\subsection{Feeding System}

The offered level of feeding was based on an expected daily DM feed intake of $3 \%$ of BW which was given during the period of adaptation. Offer levels during the collection period were based on the actual recorded intakes during the period of adaptation. Water was freely accessed through drinking nipples.

The ensiled taro, rice wine by product and fish meal were weighed and well mixed with rice bran, premix and salt, and then fed to the pigs in three feeds per day $(07.00,12.00$ and 16.00). There were no refusals of any of the feeds after feeding based on the actual recorded intakes during the period of adaptation.

\subsection{Sample Collection}

Representative samples of feeds offered were first homogenized in a coffee grinder and then immediately frozen at $-20^{\circ} \mathrm{C}$. At the end of each collection period, the samples (from each pig/period) were thawed, homogenized in the coffee grinder, sub-sampled and dried at $60^{\circ} \mathrm{C}$. Feces were collected at least 2 times/day, weighed and representative samples ( $10 \%$ of the total weight) mixed very carefully, and kept in the freezer at $-20^{\circ} \mathrm{C}$. At the end of the collection period, the samples for each pig were defrosted and homogenized before analysis. Urine was collected in a bucket containing 10 $\mathrm{ml}$ of concentrated sulphuric acid (H2SO4) to keep the $\mathrm{pH}$ below 4 so as to prevent escape of ammonia. A sub-sample $(10 \%)$ was collected each day and kept in the freezer at $-20^{\circ} \mathrm{C}$.

\subsection{Changes in Live Weight}

The pigs were weighed at the beginning of each period and at the end of the last period.

\subsection{Chemical Analysis}

The DM content was determined using the microwave method according to Undersander D, et al. (1993) [20]. pH on fresh feces was done with a $\mathrm{pH}$ meter with glass electrode. The $\mathrm{N}$ content of urine was determined by AOAC (1990) procedures [1]. NDF and ADF was analyzed according to Van Soest P J, et al. (1991) [21]. Ash, N and crude fiber were analyzed according to AOAC (1990) [1]. All the analyses were done in duplicate.

\subsection{Statistical Analysis}

The data were analyzed using the general linear model option of the ANOVA program for LSD model, using the software program of Minitab version (16) [11] with $\mathrm{P}<0.05$. Sources of variation are treatment, pigs, periods and error.

The model used was:

$$
Y i j k=\mu+A i+P j+T k+e i j k
$$

where $\mathrm{Y}=$ Dependent variable, $\mu=$ Overall mean, $\mathrm{Ai}=$ Animal, $\mathrm{Pj}=$ Period, $\mathrm{Tk}=$ Treatment, eijkl $=$ Random error. 


\section{Results and Discussion}

\subsection{Chemical Characteristics and Feed Intake}

The chemical characteristics of dietary ingredients are shown in Table 3 . The dry matter $(8.60 \%)$ and crude protein $(22.0 \%)$ in the DM of the ensiled taro were slightly lower than to those reported by Hang D T and Preston T R (2009) [8]. However, crude fiber $(31.1 \%)$ in the DM of the ensiled taro was higher than to the resulted by these authors due to the ensiled taro was made by mixing both of stem and leaves. DM $(46.8 \%)$ of rice wine by product was higher than to the results reported by Phiny C, et al. (2012) [5]. However, CP (10.5\%) of rice wine by product was lower than to that reported by these authors. The contrast results were probably caused by the different adding the yeast levels from rice wine producers. The crude protein $(52.2 \%)$ and organic matter $(67.8 \%)$ in the DM of the fish meal were higher than to the report found by Buntha P, et al. (2007) [15] but dry matter (88.1\%) of fish meal in current study was similar to those authors. DM (87.8\%), CP $(10.1 \%)$ and $\mathrm{CF}(4.95 \%)$ of rice bran in the present research were similar to the results found by Hang D T and Preston T R (2009) [8] but CF (76.2\%) of rice bran was slightly lower than found by these authors.

Table 3. Chemical composition of the feed ingredients (\% as DM).

\begin{tabular}{|c|c|c|c|c|c|c|}
\hline \multirow{2}{*}{ Ingredients } & \multirow{2}{*}{ DM \% } & \multicolumn{5}{|c|}{ As \% of DM } \\
\hline & & $\mathbf{C P}$ & OM & $\mathbf{C F}$ & NDF & ADF \\
\hline Ensiled Taro $(\mathrm{ET})$ & 8.60 & 22.0 & 82.3 & 31.1 & 45.7 & 44.8 \\
\hline Rice wine by product (RWB) & 46.8 & 10.5 & 98.7 & 1.60 & 7.80 & 1.56 \\
\hline Fish meal (FM) & 88.1 & 52.2 & 67.8 & 1.89 & 33.2 & 26.8 \\
\hline Rice bran (RB) & 87.8 & 10.1 & 76.2 & 4.95 & 25.9 & 19.7 \\
\hline Premix plus salt (PS) & 98.0 & nd & nd & nd & nd & nd \\
\hline
\end{tabular}

nd=not determined

The pigs were in good health and gained in live weight during the trial. There were no symptoms or signals of discomfort from the consumption of the diets.

\subsection{Feed Intake}

The total intakes of dry matter (DM), crude protein (CP) and organic matter $(\mathrm{OM})$ were higher in the treatments that contained rice wine by product of $20 \%$ and rice wine by product plus fish meal of $10 \%$ (Table 4 and Figure 1). As the percentages of crude fiber (CF), neutral detergent fiber (NDF) and Acid detergent fiber (ADF) were lower intakes of these fractions in the treatment without used the rice wine by product of $20 \%$ or used rice by product of $20 \%$ mixed with fish meal of $10 \%$ (Table 4 and Figure 1).

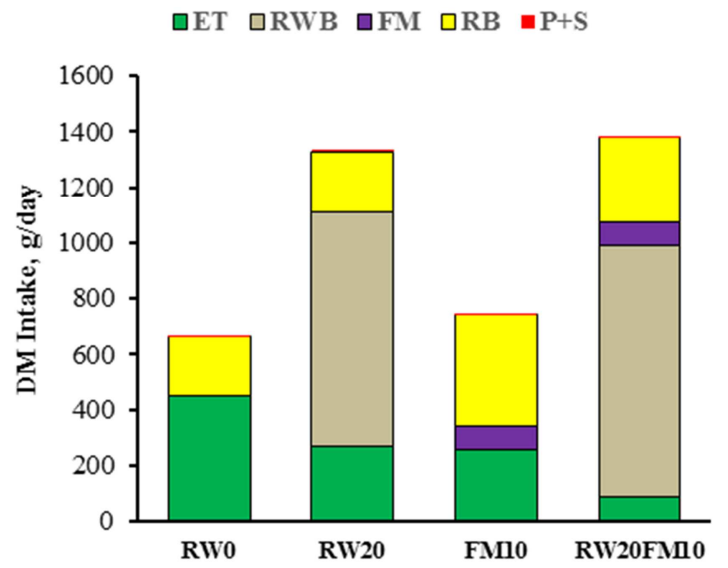

Figure 1. Feed intake in pigs fed the ensiled taro with rice wine by product or fish meal mixed with a basal diet of rice bran.

Table 4. Mean values of feed intake in pigs fed the ensiled taro with rice wine by product or fish meal mixed with a basal diet of rice bran.

\begin{tabular}{|c|c|c|c|c|c|c|}
\hline & RW0 & RW20 & FM10 & RW20FM10 & SEM & P-value \\
\hline \multicolumn{7}{|l|}{ DM intake, g/day } \\
\hline ET & 449 & 267 & 258 & 87.6 & 6.56 & \\
\hline RWB & - & 843 & - & 905 & 15.2 & \\
\hline FM & - & - & 81.3 & 78.5 & 1.31 & \\
\hline $\mathrm{RB}$ & 214 & 218 & 403 & 307 & 7.49 & \\
\hline PS & 3.93 & 3.67 & 4.05 & 3.92 & 0.09 & \\
\hline Total & $666^{\mathrm{b}}$ & $1331^{\mathrm{a}}$ & $746^{\mathrm{b}}$ & $1382^{\mathrm{a}}$ & 25.9 & $<0.001$ \\
\hline Total OM, g/day & $532^{\mathrm{b}}$ & $1216^{\mathrm{a}}$ & $548^{\mathrm{b}}$ & $1226^{\mathrm{a}}$ & 22.5 & $<0.001$ \\
\hline Total CF, g/day & $130^{\mathrm{a}}$ & $127^{\mathrm{a}}$ & $96.0^{\mathrm{b}}$ & $83.5^{\mathrm{c}}$ & 2.59 & $<0.001$ \\
\hline Total NDF, g/day & $247^{\mathrm{a}}$ & $231^{\mathrm{ab}}$ & $224^{\mathrm{b}}$ & $197^{\mathrm{c}}$ & 5.18 & $<0.001$ \\
\hline Total ADF, g/day & $257^{\mathrm{a}}$ & $242^{\mathrm{a}}$ & $247^{\mathrm{a}}$ & $215^{\mathrm{b}}$ & 5.49 & $<0.001$ \\
\hline
\end{tabular}

abcd Mean values within row without a common letter are different at $\mathrm{P}<0.05$

\subsection{Apparent Digestibility}

The DM content of the feces was non-significant different for the diets containing with or without rice wine by product (Table 5). This was probably because of the satisfying DM intake on these diets, which would be associated with a lower 
rate of passage of digesta and therefore less time for water absorption from the digesta. The higher output of faeces on the diets with the rice wine by product were slightly lower than the observations of Phiny C, et al. (2012) [5] as the diets used by these authors were taro silage mixed with cassava root meal plus sugar palm syrup. The $\mathrm{pH}$ content of the faeces and urine were non-significant different for the diets containing with or without rice wine by product. However, the faeces were higher for the diet feeding without rice wine by product.

Table 5. Mean values for faecal and urinary characteristics in pigs fed the ensiled taro with rice wine by product or fish meal mixed with a basal diet of rice bran.

\begin{tabular}{|c|c|c|c|c|c|c|}
\hline & RWO & RW20 & FM10 & RW20FM10 & SEM & P-value \\
\hline $\mathrm{DM}, \%$ & 29.8 & 30.4 & 30.8 & 29.8 & 0.43 & 0.249 \\
\hline \multicolumn{7}{|c|}{ Faecal excretion, g/day } \\
\hline Fresh material & $471^{\mathrm{b}}$ & $666^{\mathrm{a}}$ & $422^{b}$ & $667^{\mathrm{a}}$ & 15.3 & $<0.001$ \\
\hline Dry material & $140^{\mathrm{b}}$ & $203^{\mathrm{a}}$ & $130^{\mathrm{b}}$ & $199^{\mathrm{a}}$ & 5.26 & $<0.001$ \\
\hline Water & $331^{\mathrm{b}}$ & $463^{\mathrm{a}}$ & $292^{\mathrm{b}}$ & $468^{\mathrm{a}}$ & 10.9 & $<0.001$ \\
\hline \multicolumn{7}{|l|}{$\mathrm{pH}$} \\
\hline Faeces & $6.71^{\mathrm{a}}$ & $6.5^{\mathrm{b}}$ & $6.56^{\mathrm{ab}}$ & $6.69^{\mathrm{ab}}$ & 0.053 & 0.012 \\
\hline
\end{tabular}

ab Mean values within row without a common letter are different at $\mathrm{P}<0.05$

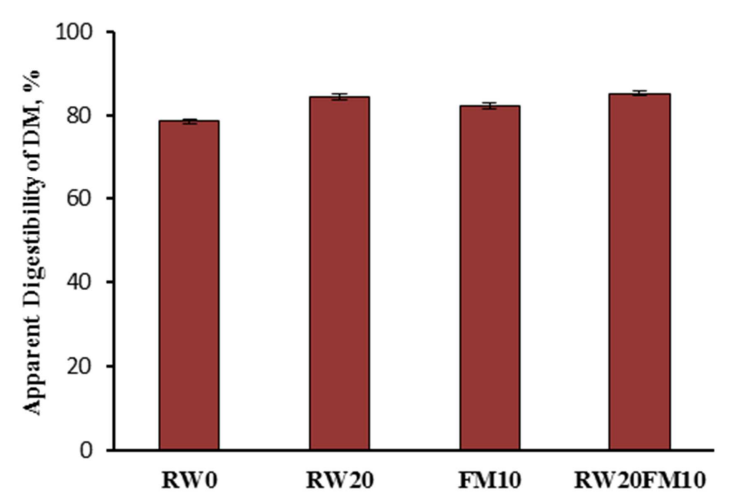

Figure 2. Apparent digestibility of DM for pigs fed the ensiled taro with rice wine by product or fish meal mixed with a basal diet of rice bran.

There were no consistent differences in apparent digestibility of DM, OM, CP and ADF except CF and NDF among the diets (Table 6, Figures 2 and 3). The values were relatively high for all the treatments contained rice wine by product while the basal diet of rice brain was mixed but except the values of CF and NDF. The apparent digestibility of DM, $\mathrm{OM}$ and $\mathrm{CP}$ increased when the diets were mixed with rice wine by product and these results were contrasted to the results reported by Manivanh N, et al. (2012) [12]. However, the apparent digestibility of DM, OM and CP in current results were similar to the finding reported by Lotchana $\mathrm{T}$ and Preston T R (2010) [16] which the treatment was contained rice wine by product to the both of different breed of pigs. By the way, the values of apparent digestibility of $\mathrm{CP}, \mathrm{CF}, \mathrm{NDF}$ and ADF in the treatment with fish meal and without rice wine by product were high as compared to other treatments, and the present findings were similar to the results found by Hang D T, et al. (2016) [6] but in contrast to the apparent digestibility of $\mathrm{OM}$ as compared to the findings currently.

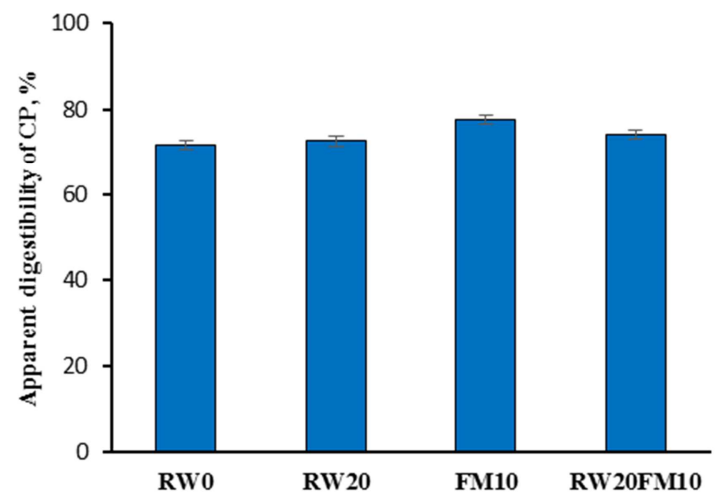

Figure 3. Apparent digestibility of $C P$ for pigs fed the ensiled taro with rice wine by product or fish meal mixed with a basal diet of rice bran.

Table 6. Mean values of apparent digestibility for pigs fed the ensiled taro with rice wine by product or fish meal mixed with a basal diet of rice bran.

\begin{tabular}{llllll}
\hline & RW0 & RW20 & FM10 & RW20FM10 & SEM \\
\hline Dry Matter (DM) & $78.6^{\mathrm{c}}$ & $84.4^{\mathrm{ab}}$ & $82.3^{\mathrm{b}}$ & $85.4^{\mathrm{a}}$ & 0.65 \\
Organic Matter (OM) & $78.1^{\mathrm{d}}$ & $84.7^{\mathrm{c}}$ & $81.6^{\mathrm{b}}$ & $87.2^{\mathrm{a}}$ & 0.64 \\
Crude Protein (CP) & $71.9^{\mathrm{b}}$ & $72.6^{\mathrm{ab}}$ & $77.8^{\mathrm{a}}$ & $74.1^{\mathrm{ab}}$ & $<0.001$ \\
Crude Fiber (CF) & $65.7^{\mathrm{b}}$ & $67.7^{\mathrm{ab}}$ & $71.8^{\mathrm{a}}$ & $60.2^{\mathrm{c}}$ & $<01$ \\
Neutral Detergent Fiber (NDF) & $68.9^{\mathrm{ab}}$ & $68.0^{\mathrm{b}}$ & $73.2^{\mathrm{a}}$ & $63.6^{\mathrm{c}}$ & 1.30 \\
Acid Detergent Fiber (ADF) & $70.8^{\mathrm{b}}$ & $70.7^{\mathrm{b}}$ & $76.1^{\mathrm{a}}$ & $67.1^{\mathrm{b}}$ & $<01$ \\
\hline
\end{tabular}

abc Mean values within row without a common letter are different at $\mathrm{P}<0.05$

\subsection{Nitrogen Balance}

Values for $\mathrm{N}$ retention, expressed as $\mathrm{g} /$ day or as a percentage of $\mathrm{N}$ intake or $\mathrm{N}$ digested, were highest for the diet with mixed rice wine by product (Table 7 , Figures $4,5,6$ and 7) with a tendency for the diet without mixed rice wine by product (FM10) to be also better than the diets without rice wine by product or fish meal (RW0). When the data for $\mathrm{N}$ retention were corrected for differences in $\mathrm{N}$ intake therefore the differences in $\mathrm{N}$ retention were more pronounced in favor of the diets 
containing rice wine by product (RW20 and RW20FM10) or without rice wine by product (FM10). The findings were similar tendencies to the report found by Manivanh N, et al. (2012) [12] when the diets were mixed with increased levels of rice distiller by product $(10,20$ and $30 \%)$ to replace the ensiled taro foliage, and similar to the findings resulted by Hang D T, et al. (2016) [6] while the ensiled taro silage was mixed with rice wine by product or fish meal. However, the results currently were contrasted to the results observed by Hang D T, et al. (2016) [6] of which $\mathrm{N}$ retention were highest when the diets were contained fish meal without the ensiled taro leaves. The difference was probably caused by lack of sugar content in the taro stem that cannot associated to increase the flavor in the silage diet for the pigs.

Table 7. $N$ balance in pigs fed the ensiled taro with rice wine by product or fish meal mixed with a basal diet of rice bran.

\begin{tabular}{|c|c|c|c|c|c|c|}
\hline & RW0 & RW20 & FM10 & RW20FM10 & SEM & P-value \\
\hline \multicolumn{7}{|l|}{$\mathrm{N}$ balance, $\mathrm{g} /$ day } \\
\hline Intake & $19.3^{d}$ & $27.1^{\mathrm{b}}$ & $22.4^{\mathrm{c}}$ & $29.8^{\mathrm{a}}$ & 0.61 & $<0.001$ \\
\hline Faeces & $7.99^{\mathrm{b}}$ & $11.6^{\mathrm{a}}$ & $9.76^{\mathrm{b}}$ & $12.2^{\mathrm{a}}$ & 0.37 & $<0.001$ \\
\hline Retention & $5.90^{\mathrm{c}}$ & $8.20^{\mathrm{ab}}$ & $7.69^{\mathrm{bc}}$ & $9.97^{\mathrm{a}}$ & 0.61 & $<0.001$ \\
\hline \multicolumn{7}{|l|}{ Retention as $\%$ of } \\
\hline Intake & 29.8 & 28.7 & 33.3 & 32.6 & 1.91 & 0.268 \\
\hline
\end{tabular}

abcd Mean values within row without a common letter are different at $\mathrm{P}<0.05$

The implication from the results of this experiment is that the biological value of the protein in rice wine by product for treatment RW20 and RW20FM10 were superior as compared to the treatment RW0 and FM10. The fact that apparent digestibility and $\mathrm{N}$ retention were higher on the diets containing rice wine by product than on the diets without contained rice wine by product lends further support to this conclusion.

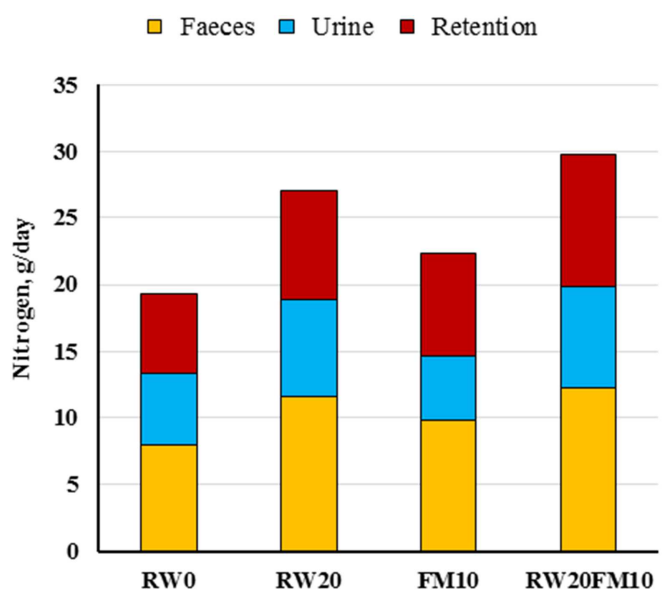

Figure 4. $N$ balance in pigs fed the ensiled taro with rice wine by product or fish meal mixed with a basal diet of rice bran.

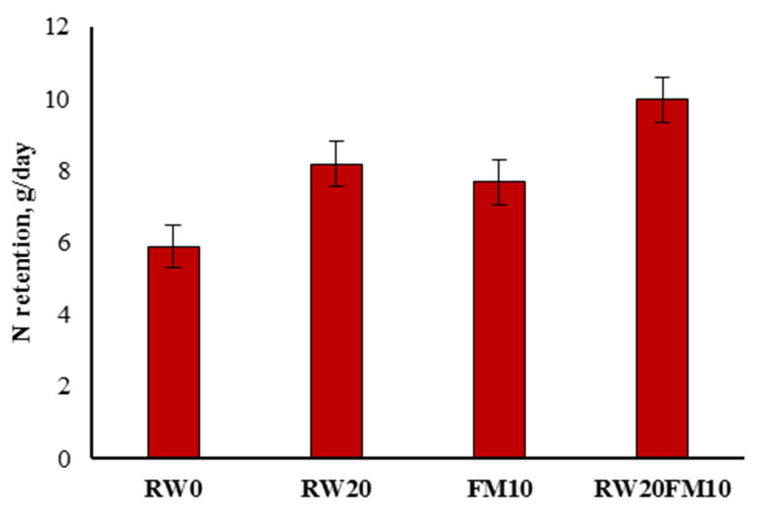

Figure 5. $N$ retention in pigs fed the ensiled taro with rice wine by product or fish meal mixed with a basal diet of rice bran.

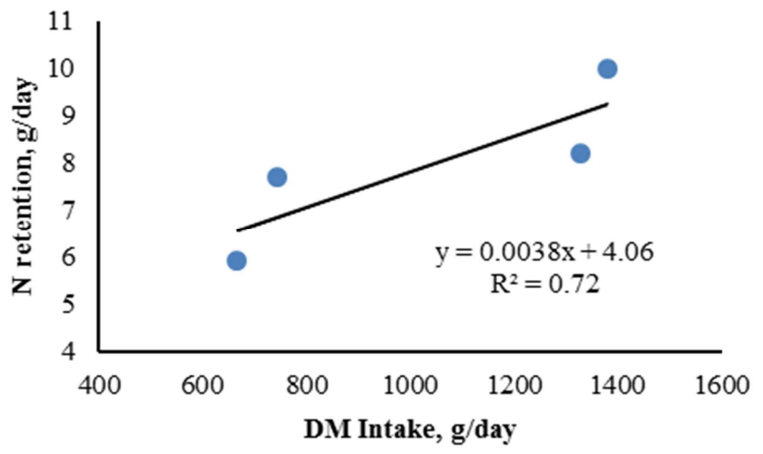

Figure 6. Relationship between DM intake and $N$ retention in pigs fed the ensiled taro with rice wine by product or fish meal mixed with a basal diet of rice bran.

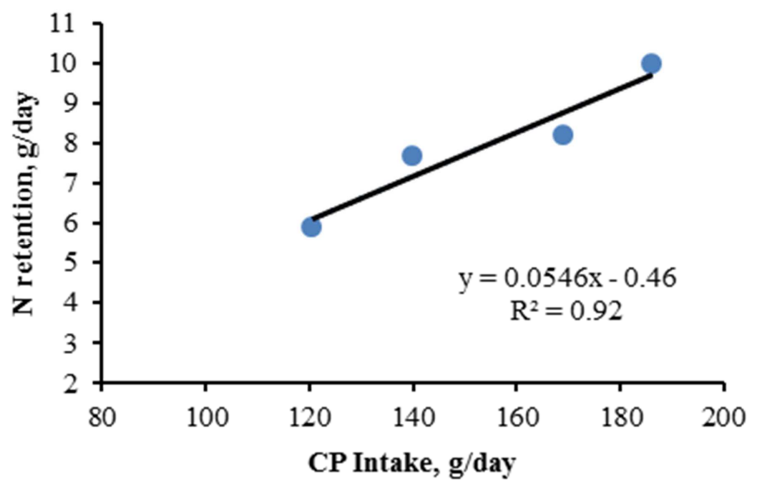

Figure 7. Relationship between $C P$ intake and $N$ retention in pigs fed the ensiled taro with rice wine by product or fish meal mixed with a basal diet of rice bran.

\section{Conclusions}

Total intakes of DM, CP and OM were higher in the treatments that contained rice wine by product (RW20) and rice wine by product plus fish meal (RW20FM10). As the percentages of CF, NDF and ADF were lower intakes of these fractions in the treatment without used the rice wine by product (RW0) or used rice by product plus fish meal (FM10).

There were no consistent differences in apparent 
digestibility of DM, OM, CP and ADF, except CF and NDF among the diets. The values were relatively high for all the treatments contained rice wine by product while the basal diet of rice brain was mixed but except the values of CF and NDF.

Values for $\mathrm{N}$ retention, expressed as $\mathrm{g} / \mathrm{day}$ or as a percentage of $\mathrm{N}$ intake or $\mathrm{N}$ digested, were highest for the diet with mixed rice wine by product with a tendency for the diet without mixed rice wine by product (FM10) to be also better than the diets without rice wine by product or fish meal (RW0).

The overall conclusion is that supplement of a mixture of the ensiled taro with rice wine by product in the diets contained RW20 and RW20FM10, were higher apparent digestibility of $\mathrm{DM}, \mathrm{CP}, \mathrm{OM}$ and $\mathrm{CF}$, and higher $\mathrm{N}$ retention, than when supplement was only ensiled taro without rice wine by product (RW0) or fish meal (FM10), mixed with a basal diet of rice brain.

\section{Acknowledgements}

The authors wish to grateful thanks to the HEIP Project has financed by World Bank via Ministry of Education Youth and Sport (MoEYs) for supporting this research. Grateful thanks to Faculty of Agriculture, Svay Rieng University to give a chance for me to carry out the experimental research on station.

\section{References}

[1] AOAC. (1990). Official Methods of Analysis. Association of official analytical chemists. $15^{\text {th }}$ edition (K Helrick editor). Arlington pp 1230.

[2] Buntha P, Borin K, Preston T R and Ogle B. (2008). Survey of taro varieties and their use in selected areas of Cambodia. Livestock Research for Rural Development. Volume 20, supplement. http://www.lrrd.org/lrrd20/supplement/bunt1.htm

[3] Chhay Ty, Borin K and Preston T R. 2010. Effect of Taro (Colocasia esculenta) leaf + stem silage and mulberry leaf silage on digestibility and $\mathrm{N}$ retention of growing pigs fed a basal diet of rice bran. Livestock Research for Rural Development. Volume 22, Article \#109. http://www.lrrd.org/lrrd22/6/chha22109.htm

[4] Chittavong M, Preston T R and Ogle B. 2006. Ensiling leaves of Taro (Colocasia esculenta) with sugar cane molasses. Workshop-seminar "Forages for Pigs and Rabbits" MEKARN-CelAgrid, Phnom Penh, Cambodia, 22-24 August 2006. http://www.mekarn.org/proprf/mala.htm

[5] Chiv Phiny, T R Preston, Khieu Borin and Mao Thona. 2012. Effect on growth performance of crossbred pigs fed basal diet of cassava root meal and ensiled taro foliage supplemented with protein-enriched rice or fish meal. Livestock Research for Rural Development. Volume 24, Article\#65. http://www.lrrd.org/lrrd24/4/phin24065.htm

[6] Hang D T, Hai V V, Hai P V, Tra T T, Qui N D and Ngoan L D. 2016. Ileal and total tract digestibility in growing pigs fed ensiled taro leaves as partial replacement of fish meal, maize and rice bran. Livestock Research for Rural Development. Volume 28 (6).
[7] Hang D T and Preston T R. 2010. Effect of processing Taro leaves on oxalate concentrations and using the ensiled leaves as a protein source in pig diets in central Vietnam. Livestock Research for Rural Development. Volume 22, Article \#68. http://www.lrrd.org/lrrd22/4/hang22068.htm

[8] Hang D T and Preston T R. 2009. Taro (Colocacia esculenta) leaves as protein source for growing pigs in Central Viet Nam. Livestock Research for Rural Development 2009 Vol. 21 No.10 pp.164 ref.8. http://www.lrrd.org/lrrd21/10/hang21164.htm

[9] Hang D T, Binh L V, Preston T R and Savage G P. 2011. Oxalate content of different taro cultivars grown in central Viet Nam and the effect of simple processing methods on the oxalate concentration of the processed forages. Livestock Research for Rural Development. Volume 23, Article \#122. http://www.lrrd.org/lrrd23/6/hang23122.htm

[10] Luu Huu Manh, Nguyen Nhut Xuan Dung, Kinh L V, Binh T C, Thu Hang B P and Phuoc T V. 2009. Composition and nutritive value of rice distillers"e by-product (hem) for small-holder pig production. Livestock Research for Rural Development Volume 21, Article \#224, from: http://www.lrrd.org/lrrd21/12/manh21224.htm

[11] MINITAB 16. 2006. Minitab software is a statistical program designed for data analysis. https://en.freedownloadmanager.org/users-choice/Download_ Minitab_16.html

[12] Manivanh N, Le Duc Ngoan and T R Preston. 2012. Apparent digestibility and $\mathrm{N}$ retention in growing pigs fed rice bran supplemented with different proportions of ensiled Taro foliage (Colocacia esculenta) and rice distillers' by-product. Livestock Research for Rural Development. Volume 24, Article \#12.

[13] Oscarsson K V and Savage G P. 2006. Composition and availability of soluble and insoluble oxalates in raw and cooked taro (Colocasia esculenta var. Schott) leaves. Food Chemistry. Volume 101, Issue 2, 2007, Pages 559-562.

[14] Oosterwijk, G, Van Aken D and Vongthilath. 2003. A manual on Improved Rural Pig Production (1st Edition, English Language). Department of Livestock and Fisheries, Ministry of Agriculture and Forestry, Vientiane, Lao PDR VIII + 113 pp. Page 21, from: http://www.smallstock.info/reference/FAO/APHCA/Pig_Eng_ ebook.pdf

[15] Pheng Buntha, Khieu Borin, T R Preston and B Ogle. 2007. Digestibility and nitrogen balance studies in pigs fed diets with ensiled taro (Colocasia esculenta) leaves as replacement for fish meal. Livestock Research for Rural Development. http://www.lrrd.org/lrrd20/supplement/bunt2.htm

[16] Lotchana Taysayavong and T R Preston. 2010. Effect of rice distillers' by-product on growth performance and digestibility of Moo Laat and Mong Cai pigs fed rice bran and water spinach. Swedish University of Agricultural Sciences Department of Animal Nutrition and Management. ISBN 978-91-86197-93-3.

[17] Luu Huu Manh, Nguyen Nhut Xuan Dung and Lindberg J E. 2003. Effects of replacement of fish meal with rice distiller's waste (hem) on performance and carcass quality of growing pigs. Proceedings of Final National Seminar-Workshop on Sustainable Livestock Production on Local Feed Resources (Editors: Reg Preston and Brian Ogle). HUAF-SAREC, Hue City, 25 - 28 March, 2003. Retrieved May 18, 110, from: http://www.mekarn.org/sarec03/manh3.htm 
[18] Luu Huu Manh. 2000. Composition and nutritive value of rice distillers' by-product (hem) for small-holder pig production, from: http://www.mekarn.org/sarpro/manh.htm

[19] Rodríguez L and Preston T R. 2009. Effect of planting method on biomass yield of New Cocoyam (Xanthosoma sagittifolium). Livestock Research for Rural Development. Volume 21, Article \#137.
[20] Undersander D, Mertens D R and Theix N. 1993. Forage analysis procedures. National Forage Testing Association. Omaha pp 154.

[21] Van Soest P J, Robertson J B and Lewis B A. 1991. Methods for dietary fibre, neutral detergent fibre and non-starch polysaccharides in relation to animal nutrition. Journal of Dairy Science 74: 3583-3597. 